Na. Vijayashankar:

\title{
Ethics for Indian Cybertariats - LAG Neutrality Challenges and Solutions
}

\begin{abstract}
:
The growth of Cybertariats as a new class of workers who represent an integration of the Cyber Society work with existence in Physical space has opened up new challenges in the management of the work force.

The key concerns or issues are those which arise in the world of Cybertariats because of the "LAG neutrality" namely the "Location Neutrality", "Age Neutrality" and "Gender Neutrality" of a Cybertariat worker.
\end{abstract}

Agenda:

Impact of Location Neutrality 16

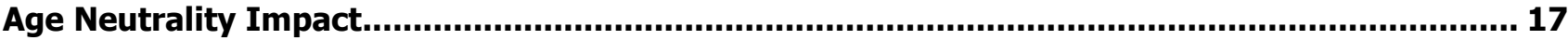

Gender Neutrality Impact.

\section{Author:}

Na.Vijayashankar

- No 37, "Ujvala" 20th Main, BSK First Stage, Bangalore 560050 naavi9@gmail.com

- Naavi is the popular name by which Na.Vijayashankar, is known in the Cyber space. Naavi is an Information Assurance consultant and Operates from Bengalooru (Bangalore) in India. Though not a lawyer, Naavi is a pioneer and an acknowledged expert in the field of Cyber Laws.

- Relevant publicaions:

- He is the author of the first book on Cyber Laws in India titled "Cyber Laws for Every Netizen in India" and the first E-Book on Cyber Laws "Cyber Laws..ITA-2000 and Beyond".

- Naavi is also the author of a book in Kannada titled "Antarjaala AparaadhagaLu" released in 2005.

- He is also the author of "Cyber Laws Demystified" which is a comprehensive discussion on Cyber Laws released in 2006.

- In 2010 Naavi released the book "Cyber Laws for Engineers", an E Book version of which has been released in 2011 along with two other books "Cyber Laws for Every one" and "Cyber Crimes and ITA 2008". 


\section{Impact of Location Neutrality}

The first and foremost issue regarding the rise of Cybertariat workforce is the impact on the local employment and the issues arising therefrom.

The Cybertariat workforce is location independent since they can work from anywhere and anytime and still are virtually present in the workplace. The industry loves them because they can hire them by shopping economically across the globe and also fire them without as much of an impact as it creates when they fire the physical workforce. The industry can keep only the "Work Goal" as the criteria for maintaining the Cybertariat work force and free themselves from other distracting aspects of human management.

The Cybertariat workforce essentially works on a Virtual identity. In many instances the real identity may not matter at all. Most commercial workforce which are distant from the national security domains do not need either an identified work force nor a permanent workforce. They can be hired and fired like a "Job Worker".

What makes an economic sense for the businessmen to hire Cybertariat workers instead of the physical workers, creates a serious ethical issue of whether industries can be oblivious of the social impact of local job losses to technology workers from another place.

The frequent references of Obama and now Donald Trump to Bengaluru IT industry as a threat to US economy stems from the fact that, for a Chicago company, the remote Bengaluru worker may be more efficient and more economical than a comparable worker sitting in Chicago. While this does affect the employment potential in the physical space of Chicago, the profitability and global competitiveness of the US Company which opts to use a Cybertariat Bengalurian instead of the US based Chicago resident, improves.

Whether the trade-off of possible local un-employment with more profit generation for the company/country is beneficial or not is an economic decision. However, this also raises the ethical issue of whether it is the responsibility of the industry to share its prosperity with the local community by providing a stable employment scenario to the community so that the community lives in harmony.

In the recent days, concerns to the Cybertariat hiring are arising because of the "Security Issues". Any cyber work involves handling of data which is personal and some times also sensitive. The security of such data is therefore a concern for "Privacy" as a part of the democratic tradition and also as a means of preventing Cyber Crimes.

A standing example of how "Privacy" and "Security" concerns affect the Cybertariat workforce is evident in the fact that after the increasing number of data theft reports from USA, the flourishing "Home Based Medical Transcription Industry" in India seems to be withering away.

A workable solution towards balancing better economic sense with softening of the local sentiments is to be worked through a "Corporate Social Program" which makes it obligatory for the Cybertariat employer to contribute to the development of alternate employment opportunities for the local workforce.

If for example, the cities of Bengaluru and Chicago enter into a Cybertariat Workforce Treaty, they can ensure that Obama need not introduce a "Bengaluru Tax" nor Trump needs to put an embargo on "Export of Data" to Bengaluru but negotiate a reverse flow of benefits from Bengaluru to Chicago either in the form of cyber related work at a different level or even through import of say manufactured goods from Chicago to Bengaluru. 


\section{Age Neutrality Impact}

As compared to the Location Neutrality, the Age Neutrality raises an issue of whether "Earning Potential" of an individual needs to be "Retired" after a person attains a particular age. In a society where "Old Age Security" is important with raising life span and decreasing family support at old age, it is some times cruel to retire an otherwise able and efficient worker just because his age certificate indicates that he has crossed a certain age.

Cybertariat workforce are free from this obligation of "Retirement" both because they work on short term assignments as well as with a focus on work output rather than other considerations.

The Cybertariat employers however have not yet fully exploited the potential of "Age Neutrality" of workforce as we still see them going with the normal recruitment norms applicable for the physical world. They therefore look at providing "Work From Home" option to persons who love to drive to their office rather than being confined to within their homes in front of their parents. On the otherhand, a middle aged person who loves to work from home and also attend to some obligations associated with staying at home would love the work from home concept more than driving down to work. Work from home for such middle aged and seniors would be a blessing and they would provide better output per unit of investment to the hirer.

Again this age neutrality could raise an ethical issue of the obligation of industry to support the younger generation who is looking for a "Primary Source of Income" for earning a livelyhood rather than providing additional revenue as a supplementary income to a middle aged or senior worker who already have enough savings for his basic necessities .

Balancing the requirements of the young society with the senior society is therefore an obligation that the Cybertariat industry needs to manage.

Again, the solution lies in generating specific alternate avenues of employment which the younger generation consider it an enjoyable occupation in replacement of the not so enjoyable nine to five office job which can be split into two or three slots and filled up by multiple senior persons working from home.

\section{Gender Neutrality Impact}

The third key aspect of Cybertariat workforce is the fact that the concept of "Good Looking", "Male or Female" has no relevance to the work.

In certain types of work, "Voice" could be a factor of employment but with some voice changing software available in the market, real time voice changing could be a technically and commercially feasible option to be used by Cybertariat workers to completely negate the advantages or disadvantages of the gender of a Cybertariat worker even when the work involves a voice interaction.

In countries like India, we are still struggling with concepts such as "Gender based Reservation" and "Gender Based Discrimination" in workforce policies. Rise of Cybertariat workforce kills the concept of such gender based discrimination and brings in an equality between the male and female workforce. It eases the obligations of the employer such as extending leave to employees beyond certain limits only on gender based considerations and generally helps in improving the productivity of the entire workforce.

Again the advantage that the Gender Neutrality provides to the Cybertariat employer also provides a challenge to the ethical obligations that the society may like to pursue in providing employment based on the gender of the employee.

While the gender neutrality may reduce the preference that the society now provides to women in the form of easy working hours and longer maternity leave etc., Cybertariat workers simply do not care about working 
hours and maternity leave since they can work as long as their health permits and be beneficial to both themselves and the employer.

In summary we may observe that there are several ethical issues that arise out of the rise of Cybertariat work force. But these provide several economic benefits to the employer and the disadvantages are often a reflection of our expectations created because of our experience with the workspace in the physical world. As we get used to the Cybertariat work space, we can certainly find a balance between the economic advantages and ethical challenges and perhaps achieve a better harmony and benefit to the society on the whole. Managing the transition without being bogged down by the old principles of what is an ideal work space is however a necessity to harness the benefits of Cybertariat work culture. 